\title{
SUSTAINABLE LEADERSHIP KEY FACTORS: STUDY ON PROFIT AND NON PROFIT ORGANISATIONS IN BATAM INDONESIA
}

\author{
Willy Candra ${ }^{*}$, Didi Sundiman ${ }^{2}$ \\ ${ }_{1,2}$ Management Study Program, Universal University, Sei Panas, Batam, Indonesia \\ *Corresponding author; E-mail: ${ }^{1}$ Weareonefamily351@ gmail.com; ${ }^{2}$ didi@ uvers.ac.id \\ *Corresponding author; Email: ${ }^{2} 232014169 @$ student.uksw.edu; ${ }^{2}$ apriani@ @staff.uksw.edu
}

\begin{abstract}
The purpose of this study was to examine the main factors forming sustainable leadership in organizations. The sampling method was simple random sampling, which got as many as 289 employees or members of organizations in the city of Batam. Principal Component Analysis was used in the process of analyzing the data of this study using statistical programming tools in R and R-Studio. The results of this study were the sustainability leadership of human resources in the organization formed by four factors, namely factor 1- harmony leadership, factor 2- ethical leadership, factor 3-personal value leadership and factor 4- care leadership.
\end{abstract}

Keywords: Sustainability leadership, harmony leadership, ethical leadership, personal value leadership, care leadership.

\section{Introduction}

At this time human resources are a very important factor to achieve a maximum goal. Management or development of human resources needs to be done to be more productive. The existence of management or development, my human resources can face and complete current tasks and tasks performed in the future (Susan, 2019). Human resources have a very important role in every process of activities contained in the organization. The role of human resources in the organization is the person who performs, determines and plans the goals to be achieved in the organization or company. As time goes by, ability and achievement are very difficult to obtain from existing human resources if they do not carry out debriefing or development that can have an impact on the effectiveness and efficiency of an organization (Susan, 2019).

Leadership is a process by which a leader seeks the participation of every colleague in the organization to achieve the stated goals (Kreitner \& Kinicki, 2005). Every individual who is chosen as the leader who leads him has the task to carry out the functions of the organization and determine the success of an organization or company. Every knowledge and ability in leadership must be controlled by a leader, especially in managing human resources. This is because without the knowledge and ability to manage human resources, a leader cannot achieve good results in his leadership.
According to Sjafri and Aida (2007) every leader needs to have an ability to effectively manage each employee, management skills and leadership abilities. In addition, leaders must also be able to understand and realize that the most important challenge in leading is to apply these three aspects appropriately in certain situations in order to achieve maximum results on human resources. Ethical leadership has the responsibility to achieve the vision, mission and values found in the organization. In addition, ethical leadership also has the responsibility to link the goals of the organization to coworkers and external stakeholders. The determining factor for the success of an organization is establishing a good relationship that is built with respect and mutual trust.

Servant leadership is an ethical style that is very effective in carrying out leadership and management tasks. In addition servant leadership has a very important role among several leadership styles that can produce reliable human resources. In terms of achieving organizational goals, it does not only use hard skills and knowledge, but requires soft skills of colleagues to achieve organizational goals such as attitude. Coworkers who have soft skills will have a positive impact on the work environment, thereby increasing the performance of coworkers.

Research from the Christensen-Salem, Walumbwa, Babalola, Guo, and Misati (2020), Puswiartika, Hinduan, Sulastiana, and Harding (2019), Schuh, 
Zheng, Xin, and Fernandez (2019) tries to find out how Mindful Leadership provides an impact on the process of forming the organizational climate, building relationships between employees, employee performance and the organization, forming leadership ethics in the organization. Research from the Lange and Rowold (2019) mindful leadership also shows the efficiency of the leadership evaluation process and organizational behavior which is more effective in the organization's operations.

Interest in sustainability and sustainable development is increasing in the $21^{\text {st }}$ century due to a new global economy characterized by acceleration and complexity, emerging awareness about environmental problems, and the use and exploitation of resources and related risks for future generations. The word sustainable, derived from the Latin "sub-ten" here, refers to something that can be defended and upheld, and figuratively related to something that can be tolerated that can be stated with certainty. In the fields of politics, technology, economics and ecology, this term has traditionally been sustainable showing the ability to achieve current goals without jeopardizing the future (Di Fabio \& Peiró, 2018). Human capital sustainability leadership will be supported by employee performance, mutual knowledge sharing between employees and between leaders, job satisfaction, and others. Therefore, the leader must continue to improve these things so as to improve the quality of human resources in the company or organization.

Research conducted by Song, Park, and Kang (2015) stated servant leadership has a positive influence on the sharing of knowledge between coworkers and leaders. Different from previous studies, according to Whisnant and Khasawneh (2014), servant leadership does not have a significant effect on knowledge sharing between colleagues and to leaders. According to Syafii, Thoyib, Nimran, and Djumahir (2015), leadership style influences performance. In line with research conducted by Mayasari (2016) women's leadership style has a significant influence on employee performance. In contrast to research conducted by Mulyanto and Sutrisno (2007), that leadership has no influence and is not significant between leadership style variables and employee performance.

Human resource management with the aim of promoting the welfare of colleagues is a new leadership style. This strategy has a focus on encouraging growing and resilient workers to build a thriving business and strong and sustainable organization. This leadership style is rooted in the definition of existing terms but aims to achieve a higher integration of the different functions of the four dimensions of leadership, including ethical, sustainable, attentive and servant leadership. Sustainable leadership focuses on the decision making process that is right towards resources in important aspects of work, and the development and sustainability of human resources by creating conditions of continuous learning that support and facilitate the personal and career growth of coworkers. One of the lessons that can enhance the personal and career growth of coworkers by teaching knowledge management (Wijayanti \& Sundiman, 2017). The concept of sustainable leadership integrates other aspects that are important for the prosperity and functioning of human resources optimally from a longterm perspective (Di Fabio \& Peiró, 2018).

According to Barbuto and Wheeler (2016), servant leadership is a leadership that comes from a sincere heart to serve coworkers as a top priority and treat coworkers as coworkers so that they have a close relationship between leaders and coworkers. According to Ehrhart (2004), servant leadership is the main goal in increasing the growth of co-workers not for the interests of organizations or leaders but for their personal interests. Ethical leadership is the principles, beliefs and values of true and false will illustrate the basis of organizational behavior that shows that leaders can influence colleagues in achieving organizational goals that have been set (in Alsharafi \& Rajiani, 2013). According to Kalshoven, Den Hartog and De Hoogh (2011), leaders who will always prioritize honesty and be more involved in actions that can reflect values and trust.

According to Gallagher and Tschudin (2010), ethical leadership aims to create justice that directs and empowers employees or members in an organization. Ethical leadership also creates consistency in actions with values, using behavior to communicate or uphold ethical standards, fair decisions and rewards, kindness, compassion and care for people around (Yukl, Mahsud, Hassan, \& Prussia, 2013). Mindful leadership refers to a style that is based on attention to important moments, and recognizes personal feelings and emotions, and keeps colleagues in control when under pressure (Di Fabio \& Peiró, 2018). Mindful is an awareness of one's presence at a particular time that has an impact on those around (George, 2012). Mindful Leadership is a part of emotional intelligence, and resonant leadership. Emotional intelligence consists of four parts, namely selfawareness, self-management, social awareness, and relationship management. Referring to the literature review and the results of previous studies, the hypothesis in this study is human capital sustainability leadership in 
Indonesia formed by the main factors derived from ethical leadership, sustainable leadership, mindful leadership, servant leadership.

\section{Research Methods}

In this study using quantitative research type. Quantitative research is research that collects data expressed in the form of numbers that have the aim to describe or describe the properties of a situation or object of research and conduct data analysis and hypothesis testing. (Wijayanti \& Sundiman, 2017). The analysis used in this research is factor analysis through Principal component analysis approach to find out the relationship between factors and variable variables. Principle component analysis is a factor analysis technique in which several factors will be formed in the form of latent variable that cannot be determined before the analysis is performed. In principle, this analysis produces new random factors, which can then be interpreted according to the factors or components or constructs that are formed.

The initial measurement items for constructing the survey questionnaire were achieved through several literature reviews (Di Fabio \& Peiró, 2018; Prasetiwi, 2019). Intensifying the literature review process undertaken for the sustainable development of human resources, research instruments were chosen rigorously from a variety of sources. According to the guidelines presented by (Jennex, 2015), there are several important stages in the literature review process carried out in this study. References using good quality publication sources are the first choice in the process of finding references. Researchers use several ways to collect references such as Google Scholar and Scopus indexing the publisher's website that has been used as the main reference source. The process of searching the internet is done by referring to several keywords such as Human resourses, leadership. The process of finding research instruments is carried out with in-depth analysis of each article.

Brown, Treviño, and Harrison (2005) define ethical leadership as a behavior that is carried out in accordance with applicable rules through personal actions and interpersonal relationships, and the promotion of that behavior to colleagues through two-way communication, reinforcement, and decision making. Ethical leadership focuses on the ethical dimension of leadership rather than incorporating ethics as an additional dimension Mayer, Kuenzi, Greenbaum, Bardes, and Salvador (2009). Brown et al. (2005) describe ethical leadership as including the nature and behavioral dimensions. An ethical leadership variable can be reflected in the qualities of a leader, such as integrity, social responsibility, justice, and willingness to think about the consequences of one's actions. However, ethical leadership is also reflected by certain behaviors, where leaders promote ethical work.

Leadership is a concept that is closely related to the topic of human resource development (Hitt \& Ireland, 2002). Sustainable leadership focuses on strong partners, a thriving and successful environment that is characterized by co-worker well-being and long -term performance. Mindful Leadership is a relationship between thoughts and leadership and always focus and pay attention. Studying action, attention and focus is a neuroscientific phenomenon bridging emerging knowledge about human intelligence, and is a framework that supports mindful leadership from the nature and nurturing of intelligence in influencing others towards achievement of goals (Lange \& Rowold, 2019).

According Barbuto and Wheeler (200 6) servant leadership is a leadership that starts from a sincere feeling that arises from the heart to serve, where this leadership puts the needs of employees as the top priority and treats employees as coworkers so that the closeness of the leader with employees is created very closely because of the involvement of one another.

Content analysis is one of the methods used for analysis, relational aspects and involves interpretation of the underlying meaning of the text (Creswell, 2005). This research was conducted in Batam. The time taken from the preparation of the proposal until the compilation of research reports in January 2020 to April 2020. The method of sampling in this study uses simple random sampling. Respondents were drawn from individuals who worked or were active in organizations and companies in the city of Batam. The total number of respondents who were successfully collected and met the criteria to be used was 289 data.

\section{Results and Discussion}

Based on data obtained on the characteristics of natural species, the most number of respondents in this study were $50.9 \%$ women or 147 respondents, while the number of male respondents was $49.1 \%$ or 142 respondents with a total of 289 respondents. Then, it can be concluded that more women work than men. This is caused by the number of job vacancies for women more than men. Based on data obtained by age, the number of respondents from under 20 years old is 32 respondents or $11.1 \%$, aged $20-30$ is 204 respondents or $70.6 \%$, aged 
$31-40$ is 37 respondents or $12.8 \%$, age over 40 years as many as 16 respondents or $5.5 \%$. Then it can be concluded that the number of respondents aged 20-30 more who work or are in the organization. This is due to the age between 20-30 years of age having a higher productivity. Based on the data obtained based on the length of work, the number of respondents based on the most years of work in this study was $2-5$ years as much as $53.6 \%$ or 155 respondents, the number of respondents based on the least working time was more than 10 years as many as 12 respondents or $4.2 \%$, whereas for less than 1 year 89 respondents or $30.8 \%$ and $6-10$ years 33 respondents or $11.4 \%$. Then it can be concluded that the number of respondents who worked 2-5 years longer. This is caused by the large number of respondents who cannot stay in one organization or company for longer and the high desire to try new things.

Validity test in this study was carried out using R Programming. Testing the validity of our instruments will be done by measuring the correlation between indicators with the total for each variable. Each indicator for the ethical leadership variable is valid with the value of each indicator i.e. my leader gives an example of how to do things the right way in terms of ethics (0.866), my leader in making decisions fairly by observing the norms that apply (0.916), my leader listens to employee complaints and tries to provide ethical solutions (0.846), my leader disciplines employees who violate ethics ( 0.743$)$, my leader is a leader who can be trusted (0.724). The sustainable leadership variable includes several indicators: my leader actively creates and develops sustainable learning (0.697), my leader always develops existing human resources (0.862), my leader supports my personal growth (0.816), my leader always focuses human resources on important aspects of work (0.774)

The mindful leadership variable has several indicators: my leader puts himself in the position of coworkers when doing work (0.846), my leader always anticipates coworkers' requests (0.699), my leader realizes the strengths and limitations of coworkers $(0.532)$, my leader can control yourself when with coworkers, even in stressful situations (0.676). The servant leadership variable includes several indicators: my leader is a person who has a concern for subordinates (0.9 15), my leader is a leader who gives authority to subordinates over their own work (0.9 15), my leader is a leader who has a vision for company development $(0.661)$, my leader is a leader who respects the work of subordinates $(0,719)$, my leader is a leader who has high integrity $(0,854)$. From the test results, it can be seen that the raw_alpha EL value of 0.88 indicates that the reliability value is good enough for the indicator variable EL or it can be said that the variable is reliable. From the test results, it can be seen that the raw_alpha SL value is 0.79 , indicating that the reliability value is good enough for the SL variable indicator or it can be said that the variable is reliable. it can be said that the variable is reliable. From the test results, it can be seen that the raw_alpha SvL value of 0.87 indicates the reliability value is good enough for the SvL variable indicator or it can be said that the variable is reliable.

PCA testing was carried out on 18 initial items for importance scale with oblique rotation (direct oblimin). The greater the magnitude of the eigen value of a factor, it can show more representative in representing a number of variables. The factors chosen for further analysis are factors with eigen values greater or equal to one (1) (Jolliffe, 1986). PCA testing shows that there are four main factors, namely the first factor has an eigen value of 6.3139597 with a percentage of $19.2 \%$, the second factor has an eigen value of 1.9628910 with a percentage of $15.8 \%$, the third factor has an eigen value of 1.4045861 with a percentage of $13.0 \%$ and the fourth factor has an eigen value of 1.0008719 with a percentage of $6.5 \%$.

The first factor includes various indicators such as my leader is someone who has a concern for subordinates (0.894); my leader is a leader who gives authority to subordinates over their own work $(0.831)$; my leader is a leader who has high integrity $(0.705)$; my leader can control himself when with colleagues, even in stressful situations (0.66 1); my leader is a leader who values the work of subordinates (0.654) and my leader is a leader who has a vision for company development (0.646).

The second factor includes various indicators such as my Leader disciplining employees who violate ethics (0.818); my leader in making decisions fairly by taking into account the norms that apply (0.726); my leader gave an example of how to do things the right way in terms of ethics (0.646); my leader listens to employee complaints and tries to provide ethical solutions (0.639); my leader is actively creating and developing sustainable learning $(0.615)$ and my leader is a leader who can be trusted (0.610).

The third factor includes various indicators such as my Leader always developing existing human resources 0.802 ); my leader is aware of the strengths and limitations of coworkers (0.716); my leader supports my personal growth (0.622); my leader puts him self in the position of coworkers when doing work (0.617) and my leader always focuses human resources on important 
Table 1

Results of PCA Testing $(n=289)$

\begin{tabular}{|c|c|c|c|c|}
\hline \multirow{2}{*}{ Indicator } & \multicolumn{4}{|c|}{ Rotated factor loadings } \\
\hline & HL & EL & PVL & $\mathrm{CL}$ \\
\hline My leader is someone who has concern for subordinates. & 0.894 & & & \\
\hline My leader is a leader who gives authority to subordinates over their own work. & 0.831 & & & \\
\hline My leader is a leader who has high integrity. & 0.705 & & & \\
\hline My leader can control himself when with colleagues, even in stressful situations & 0.661 & & & \\
\hline My leader is a leader who respects the work of subordinates. & 0.654 & & & \\
\hline My leader is a leader who has a vision for company development. & 0.646 & & & \\
\hline My leader disciplines employees who violate ethics & & 0.818 & & \\
\hline My leader in making decisions fairly by taking into account the norms in force. & & 0.716 & & \\
\hline My leader gave an example of how to do things the right way in terms of ethics. & & 0.646 & & \\
\hline My leader listens to employee complaints and tries to provide ethical solutions. & & 0.639 & & \\
\hline My leader actively creates and develops continuous learning & & 0.615 & & \\
\hline My leader is a leader who can be trusted & & 0.610 & & \\
\hline My leader always develops the existing human resources. & & & 0.802 & \\
\hline My leader is aware of the strengths and limitations of coworkers & & & 0.716 & \\
\hline My leader supports my personal growth. & & & 0.622 & \\
\hline My leader puts himself in the position of coworkers when doing work & & & 0.617 & \\
\hline My leader always focuses human resources on important aspects of the job. & & & 0.460 & \\
\hline My leader always anticipates coworkers' requests. & & & & 0.776 \\
\hline
\end{tabular}

aspects of work (0.460). The fourth factor includes indicators my leader always anticipates coworkers' requests (0.776).

Hypothesis testing in this study uses PCA testing using $\mathrm{R}$ programming. Analyzes were performed to obtain eigen values for each component in the data. The factor chosen for further analysis is a factor with an eigen value greater than or equal to one. The results obtained from PCA testing show that there are four main factors derived from each variable and explain $54.5 \%$ variant. To these four factors have more than one eigenvalue. Initially, the output of the analysis shows the matrix component before rotation. This matrix contains loading each variable into each factor. By default, the statistical software displays all the loading of the matrix. This is not very important for interpretation, but it is actually interesting to note that before rotation, most of the variables load heavily into the first factor.

Each factor produced is named according to the components in the same group. The factors produced are factors 1 - harmony leadership that haseigen value is equal to 6.3139597 with percentage of $19.2 \%$, factor 2 ethical leadership has an eigen value of 1,9628910 with percentage of $15.8 \%$, factor 3 - personal value leadership has eigen value is equal to 1.4045861 with percentage by $13.0 \%$ and factors 4 - care leadership has eigen value is equal to 1,0008719 with percentage of $6.5 \%$. In addition to these four main factors there are several supporting factors derived from ethical leadership, sustainable leadership, mindful leadership, servant leadership. These supporting factors have score eigen value under 1 so it doesn't have a big effect on human capital sustainability leadership.

From the results of these tests it can be concluded that the hypothesis human capital sustainability leadership in Indonesia formed by the main factors derived from ethical leadership, sustainable leadership, mindful leadership, servant leadership fulfilled.

Factor 1- harmony leadership (HL): A good leader is someone who can protect his subordinates to achieve their goals, so that subordinates do not feel oppressed. So that someone can run the organization well, then a leader needs training and mature experience in his field. If the relationship between the leader and subordinates is a harmonious and pleasant relationship, of course the subordinate will appreciate the leader. Project organization will be easier to do because the leader and subordinates have a close relationship as a "colleague", so it will be 
easier to reach mutual agreement. According to Leek (2019) democratic leadership style gives responsibility and authority to all team members so that each member is actively involved in making decisions and may provide input to members and leaders. This leadership style balances between the tasks given to be completed properly and it is important to maintain a harmonious relationship between teams.

In profit organizations, leaders are generally not in harmony with their subordinates, especially when organizational goals are not achieved. Leadership in profit organizations will not care about the circumstances experienced by their subordinates which results in not achieving the goals of the organization. This results in disharmony between the leader and his subordinates. In contrast to nonprofit organizations, when organizational goals are not achieved the leaders will discuss with members of the organization related to not achieving organizational goals and look for solutions to achieve the goals of the organization. This has led to a harmony between the leaders and members of the organization (Akingbola, Rogerrs, \& Baluch, 2019).

Factor 2 - ethical leadership (EL): Ethics refers to the values and morals that are desired and appropriate according to the individual or society in general. Ethics is related to the purity of individuals and their intentions. Ethics serves as a guide for analyzing "what is good or bad" in certain scenarios. Relating to ethics andleadership, we find that ethics is all about the identity of the leader and the role of the leader. Ethics are important for leadership because a leader moves and influences subordinates/followers to achieve common goals, whether in terms of teamwork, organizational search, or any project. It is the ethical duty of leaders to treat their subordinates with respect because each of them has a unique personality. The ethical environment in an organization is built and developed by a leader because they have an influential role in the organization and because of the fact that leaders have influence in developing organizational values.

According to Leek (2019) all autocratic leadership styles are determined by the leader, the leader is everything. All decisions taken by the leader and subordinates do not have the right to speak. The subordinates only carry out the instructions given. The pattern of communication that occurs is one direction from the leader to the subordinates. With this leadership pattern, all tasks given will definitely be completed because the leader will make sure everything goes well. Leaders who use this style are very task oriented so it is likely that there are subordinates who do not fit into this leadership style.
Generally speaking in profit organizations leaders often do unethical things. One of the unethical things is often like giving decisions in accordance with their own thoughts and desires without holding discussions first. This often creates new problems that slow down the achievement of organizational goals. In contrast to nonprofit organizations the leaders will discuss in advance with the members of the organization to reach agreement in making decisions. This can be said is an ethical action which provides a decision on joint discussion to achieve organizational goals.

Factor 3 - personal value leadership (PVL): Value as one part of leadership that is implicated in every behavior carried out within the company/organization. Every company or organization does need a strategy, strong leadership, a neat system, and people who are skilled in running a business or activity, but all of them must be bonded in the same frame in the form of the same cultural values. This will be a powerful tool in winning the hearts of employees as the motor running the company's operations. According to Leek (2019), this leadership style gives absolute freedom to subordinates to be creative. leadership that occurs is one direction from subordinates to leaders. The leader only gives a brief direction in the form of general objectives and the rest is given to subordinates. The division of tasks and groups is also left to subordinates.

In general, leadership in profit organizations leaders do not imply the value of leadership in every behavior carried out in the company/organization. Where disparities often occur between leaders and subordinates so that subordinates feel unappreciated. One of them is the leader who gives jobs that are not in accordance with the duties of his subordinates. This causes many employees to feel uncomfortable working under leadership who do not have personal values in their leadership. In contrast to leadership in non-profit organizations, in general, organizational leaders will imply their personal values in every behavior carried out within the organization.

Factor 4 - care leadership (CL): A caring leader is someone who has a genuine interest in others. He has a desire to get to know the people he works with, not so that he can do tokens from time to time because he feels he has to, but because he really wants to get to know his people and encourage them to be the best they can be they can. A caring leader is intuitive, aware of the small things. He pays attention to changes in a person's mood and will ask their well-being with open generative questions that identify individuals and what is happening to them at this time. According to Leek (2019), a leader 
with a style of transformation always strives for how to change his team to be better. This change can be in the form of additional skills and the ability to do more work faster.

In general, leadership in profit organizations is very rarely the concern for subordinates. What often happens is that many leaders do not know deeply about their employees. This results in reducing the leader's concern for his subordinates even though his subordinates have problems in the process of achieving organizational goals. Where the lack of concern for his subordinates can result in obstruction of organizational goals. In contrast to leadership in nonprofit organizations, where the leader knows deeply the members personally so that the leader can give his care appropriately. This can accelerate the achievement of organizational goals.

\section{Conclusions and Recommendations}

Based on the results of data processing above, it can be concluded that results obtained from PCA testing through $\mathrm{R}$ programming show that there are four main factors derived from each variable. The factors produced are named according to the components in the same group, namely factor 1 - harmony leadership, factor 2 ethical leadership, factor 3 - personal value leadership and factor 4 - care leadership. in addition to these main factors, there are several supporting factors derived from ethical leadership, sustainable leadership, mindful leadership, servant leadership but do not have a large influence on human capital sustainability leadership. From the test results it can be concluded that human capital sustainability leadership formed by four main factors derived from ethical leadership, sustainable leadership, mindful leadership, servant leadership.

The advice for the next researcher, the respondent should be taken not only in one area but also from various regions, and the questionnaire answers can be chosen more selectively to get better results. For companies or organizations, it can be used as a reference in improving the quality of sustainable human resources. It is expected that leaders in the organization can apply the four main factors to the achievement of organizational goals that have been set and fought together. In addition, the company provides training to leaders in order to have leadership values, especially the four main factors. Based on research results from the PCA analysis showed four main factors derived from variables can support sustainable human resources in the company or organization. Many things need to be considered in a leadership. A leader certainly must have quality attitudes for the progress of the organization and the company. In addition to being responsible, a leader must have the nature and attitude as a leader who has clear goals and vision. A leader must be able to provide encouragement to its members. As well as prioritizing humane and respectful relationships. A good leader will have positive implications and benefits for the company and its members.

The results of this study are used as input for leaders who are in companies or organizations to continue to improve quality and fix problems that exist within the company or organization. These four main factors can be used and must be owned by every leader in the company or organization. to improve the quality of existing resources in order to achieve sustainable human resources.

By implementing harmony leadership in the organization, it will provide warmth between leaders and members of the organization in achieving organizational goals. Application ethical leadership in the organization by leadership will provide a very large influence on every behavior carried out in the company/organization between organizational leaders and members of the organization. Every leader who feels personal value leadership as one part of leadership will be implicated in every behavior carried out in the company/organization. Every leader who implements care leadership in his organization, the leader will give his care to the members of the organization.

In a study there is a limitation of research, here are some limitations in this study, namely the limitations of respondents in the study, the difficulty of reaching the population of Batam city people who are working widely and comprehensively. Besides the difficulty in analyzing the results of data processing so as to allow less than the maximum analysis results.

\section{References}

Al-sharafi, H., \& Rajiani, I. (2013). Promoting organizational citizenship behavior among employees: The role of leadership practices. International $J_{o-}$ urnal of Business and Management, 8(6), 47-54. doi:10.5539/ijbm.v8n6p 47.

Akingbola, K., Rogers, S., \& Baluch, A. M. (2019). Evaluating change in nonprofit organizations. In Change management in nonprofit organizations: Theory and practice, pp. 223-250. Switzerland: Palgrave Macmillan.

Barbuto, J. E., \& Wheeler, D. W. (2016). Scale development and construct clarification of servant leadership. doi:10.1177/105960110628 7091. 
Brown, M. E., Treviño, L. K., \& Harrison, D. A. (2005). Ethical leadership: A social learning perspective for construct development and testing. Organizational Behavior and Human Decision Processes, 97, 117-134. doi:10. 1016/j.obhdp.2005.03.002.

Christensen-Salem, A., Walumbwa, F. O., Babalola, M. T., Guo, L., \& Misati, E. (2020). A multilevel analysis of the relationship between ethical leadership and ostracism: The roles of relational climate, employee mindfulness, and work unit structure. Journal of Business Ethics, 1-20. https://doi.org/10.1007/s10551-020 -04424-5.

Creswell, J. W. (2005). Educational research: Planning, conducting, and evaluating quantitative and qualitative research. Upper Saddle River, NJ: Pearson Merrill Prentice Hall.

Di Fabio, A., \& Peiró, J. M. (2018). Human capital sustainability leadership to promote sustainable development and healthy organizations: A new scale. Sustainability, 10(7), 2413, 1-11. https://doi. org/10.3390/su1007 2413.

Gallagher, A., \& Tschudin, V. (2010). Educating for ethical leadership. Nurse Educ Today, 30(3), 224 227. doi: 10. 1016/j.nedt.2009.11.003.

George, B. (2012). Mindfulness helps you become a better leader. Harvard The Business Review, 26, 21-32.

Hitt, M. A., \& Ireland, R. D. (2002). The essence of strategic leadership: Managing human and social capital. Journal of Leadership \& Organizational Studies, 9(1), 3-14.

Jennex, M. E. (2015). Literature reviews and the review process: An editor-in-chief's perspective. Соттиnications of the Association for Information Systems, 36 (8), 139-146.

Jolliffe, I. T. (1986). Principal component analysis and factor analysis. In I. T. Jolliffe, Principal component analysis, pp. 115-128. New York, NY: Springer New York. https://doi.org/ 10.1007/978-14757-1904-8_7.

Kalshoven, K., Den Hartog, D. N., \& De Hoogh, A. H. B. (2011). Ethical leadership at work questionnaire (ELW): Development and validation of a multidimensional measure. The Leadership Quarterly, 22, 51-69. https://doi. org/10.1016/j.leaqua.2010. 12.007.

Kreitner, R., \& Kinicki, A. (2005). Organizational behavior. Fifth Edition. Book 2. Jakarta: Salemba Empat.

Lange, S., \& Rowold, J. (2019). Mindful leadership: Evaluation of a mindfulness-based leader intervention. Gruppe. Interaktion. Organisation. Zeitschrift für Angewandte Organisationspsychologie
(GIO), 50(3), 319-335. https://psycnet.apa.org/ doi/10.1007/s11612-019-00482-0.

Leek, J. (2019). Decentralization policies co ncerning leadership of parents and students in school councils in Poland. From autocracy to democracy within the state monopoly. International Journal of Leadership in Education, 1-18. https://doi.org/ 10.1080/13603124 .2019.1643501.

Mayasari, D. (2016). Pengaruh gaya kepemimpinan perempuan terhadap kinerja karyawan di PT. AIA Chandra Utama Agency Kupang. AGORA, 4(1), 776-781.

Mayer, D. M., Kuenzi, M., Greenbaum, R., Bardes, M., \& Salvador, R. (Bombie). (2009). How low does ethical leadership flow? Test of a trickle-down model. Organizational Behavior and Human Decision Processes, 108(1), 1-13.

Mulyanto, \& Sutrisno. (2007). Pengaruh kepemimpinan, komunikasi, kompensasi, dan motivasi terhadap kinerja pegawai. Jurnal Manajemen Sumber Daya Manusia, 2(1), 54-58.

Prasetiwi, T. (2019). Pengaruh kepemimpinan etis terhadap kinerja karyawan dengan iklim etis dan komitmen organisasi sebagai variabel mediasi (Studi pada karyawan KSPPS BMT Tumang di Boyolali). Skripsi, Institut Agama Islam Negeri Surakarta.

Puswiartika, D., Hinduan, Z. R., Sulastiana, M., \& Harding, D. (2019). Measuring customer-oriented organizational citizenship behavior on the employees of railway transportation service provider. Binus Business Review, 10(2), 105 -112. https:// doi.org/10.21512/bbr.v1 0i2.5277.

Schuh, S. C., Zheng, M. X., Xin, K. R., \& Fernandez, J. A. (2019). The interpersonal benefits of leader mindfulness: A serial mediation model linking leader mindfulness, leader procedural justice enactment, and employee exhaustion and performance. Journal of Business Ethics, 156(4), 1007-1025. https://doi.org/10.1007/s10551-017-3610-7 .

Sjafri, M., \& Aida, V. H. (2007). Manajemen mutu sumber daya manusia. Jakarta: Ghalia Indonesia.

Song, C., Park, K. R., \& Kang, S.-W. (2015). Servant leadership and team performance: The mediating role of knowledge-sharing climate. Social Behavior and Personality: An International Journal, 43(10), 1749-1760. DOI: https: //doi.org/10.2224/ sbp.2015.43.10.1749.

Susan, E. (2019). Manajemen sumber daya manusia. ADAARA: Jurnal Manajemen Pendidikan Islam, 9(2), 952-962. DOI: 10.35673/ajmpi.v9i2.429. 
Syafii, L. I., Thoyib, A., Nimran, U., \& Djumahir. (2015). The Role of corporate culture and employee motivation as a mediating variable of leadership style related to the employee performance (Studies in Perum Perhutani). Procedia Social and Behavioral Sciences, 211, 1142-1147. https://doi.org/10.10 16/j.sbspro.2015.11.152.

Whisnant, B., \& Khasawneh, O. (2014). Serving to sharing: Understanding servant leadership influences on the tacit knowledge sharing of workers in the industry. Proceedings EAM, 6(2), 194 5-1961.
Wijayanti, D. W., \& Sundiman, D. (2012). Pengaruh knowledge management terhadap kinerja karyawan: Studi empiris pada PT. SMS Kabupaten Kotawaringin Timur. DeReMa: Jurnal Manajemen, 12(1), 69-85. http://dx.doi.org /10.19166/ derema.v12i1.243.

Yukl, G., Mahsud, R., Hassan, S. \& Prussia, G. E. (2013). An improved measure of ethical leadership. Journal of Leadership \& Organizational Studies, 20(1), 38-48. https://doi.org/10.1177/154805181 1429352. 